\title{
Reduced growth in Baltic Sea cod may be due to mild hypoxia
}

\author{
Brander, Keith
}

Published in:

ICES Journal of Marine Science

Link to article, DOI:

10.1093/icesjms/fsaa041

Publication date:

2020

Document Version

Peer reviewed version

Link back to DTU Orbit

Citation (APA):

Brander, K. (2020). Reduced growth in Baltic Sea cod may be due to mild hypoxia. ICES Journal of Marine Science, 77(5), 2003-2005. [fsaa041]. https://doi.org/10.1093/icesjms/fsaa041

\section{General rights}

Copyright and moral rights for the publications made accessible in the public portal are retained by the authors and/or other copyright owners and it is a condition of accessing publications that users recognise and abide by the legal requirements associated with these rights.

- Users may download and print one copy of any publication from the public portal for the purpose of private study or research.

- You may not further distribute the material or use it for any profit-making activity or commercial gain

- You may freely distribute the URL identifying the publication in the public portal

If you believe that this document breaches copyright please contact us providing details, and we will remove access to the work immediately and investigate your claim 


\section{Reduced growth in Baltic Sea cod may be due to mild hypoxia}

Keith Brander

Stockholm University Baltic Sea Centre

and National Institute of Aquatic Resources, Technical University of Denmark,

email: keith@aqua.dtu.dk

The paper - Feeding and growth of Atlantic cod (Gadus morhua L.) in the eastern Baltic Sea under environmental change (Neuenfeldt et al., 2019) - estimated that energy intake for $20-30 \mathrm{~cm}$ cod during the period 2004-2012 had declined to below the level required to sustain growth. The principal explanation given for the low feeding levels was that increased hypoxia had reduced the abundance of benthic prey for small cod, but no evidence was presented to show that benthic prey abundance had in fact decreased, therefore this must be regarded as an untested hypothesis. An alternative hypothesis, based on published experiments on cod (Chabot \& Dutil, 1999) (henceforth C\&D) is that they feed less when the oxygen level is low, therefore a decline in their ambient oxygen would be expected to reduce their feeding rate. This Comment tries to evaluate whether observed changes in the oxygen environment of small $(20-30 \mathrm{~cm})$ cod in the Baltic Sea and the consequent reduction in feeding rate (Figure 1) are sufficient to explain all or part of the decline in feeding and energy intake estimated by Neuenfeldt et al. (2019).

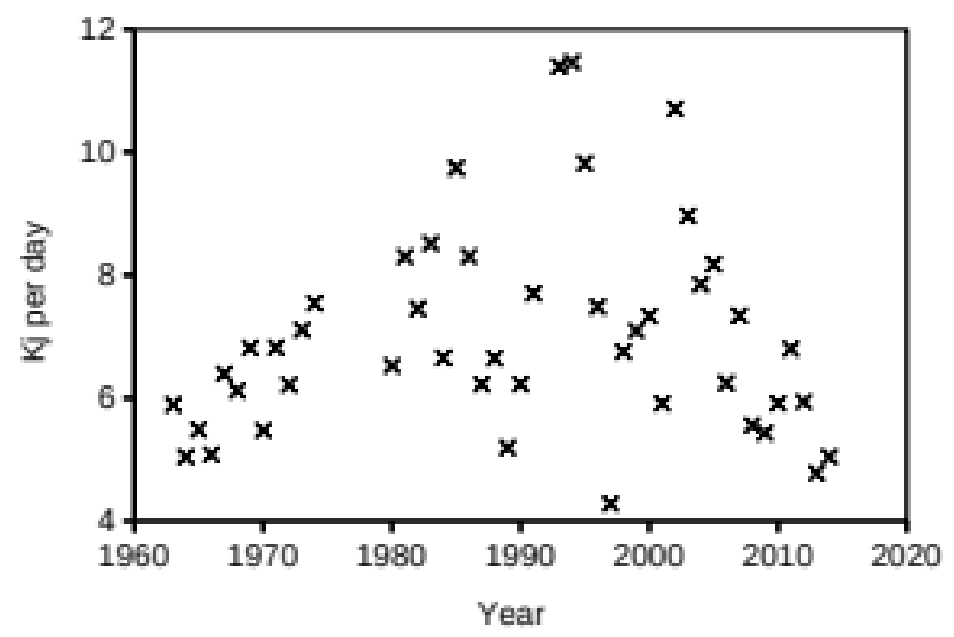

Figure 1: Trends in daily food consumption of Gadus morhua $21-30 \mathrm{~cm}$ (replotted from Figure 3 of Neuenfeldt et al. 2019) 
The Baltic Sea environment, ecosystem and cod stock have undergone major changes over the last 60 years, during which an increase in hypoxic areas has resulted in shrinkage of suitable spawning sites

20 and in the distribution of cod (Casini et al., 2016; Köster et al., 2017). Small cod are now mainly found in ICES Sub Division 25 (SD25) south of Gotland and between 14-18degE (Figure 1 of Orio et al., 2019 ) The average depth for juvenile cod in SD25 is 57m for the period 2004-2015 and the interquartile range is about $15 \mathrm{~m}$. Since 1980 the mean depth distribution of juvenile cod in this area has deepened by about $2.5 \mathrm{~m}$ per decade, perhaps due to increased predation by seals and cormorants

25 (Orio et al., 2019). The changes in the Baltic Sea over the past century (predators, fishing, nutrient input, inflows) have affected cod stocks and feeding rates in different ways over time; the processes and interactions are not simple. Although the relationship between oxygen level and individual cod feeding is probably unchanging over time, the ambient oxygen experienced by the population will vary due to changes in location and depth.

30 Cod stomach content data (downloaded from ices.dk on 6/12/2019) were analysed to calculate the proportions by weight of benthos and fish in the diet in SD25. Cod $<30 \mathrm{~cm}$ contained $>90 \%$ benthos and cod $>45 \mathrm{~cm}$ contained $>50 \%$ fish. Small cod that feed almost exclusively on benthos can be expected to spend much of their time on or close to the seabed. The average oxygen level in the bottom $5 \mathrm{~m}$ of the water column was therefore used to represent the ambient oxygen level for small cod and

35 oxygen data for SD25 were extracted and analysed accordingly ( downloaded from ices.dk on 6/12/2019).

Monthly averages of data grouped into $20 \mathrm{~m}$ bottom depth bins show that the amount of oxygen declines by about $1 \mathrm{ml} / \mathrm{l} / 10 \mathrm{~m}$ depth increase and the amplitude of seasonal variability (2-3ml/l) also declines with bottom depth (Figure 2a). Oxygen has declined slowly since 1960 (Carstensen, Andersen, 40 Gustafsson, \& Conley, 2014) but since 2010 the trend has been much steeper, with a drop of roughly 2ml/l per decade (Figure $2 \mathrm{~b}$ ). 

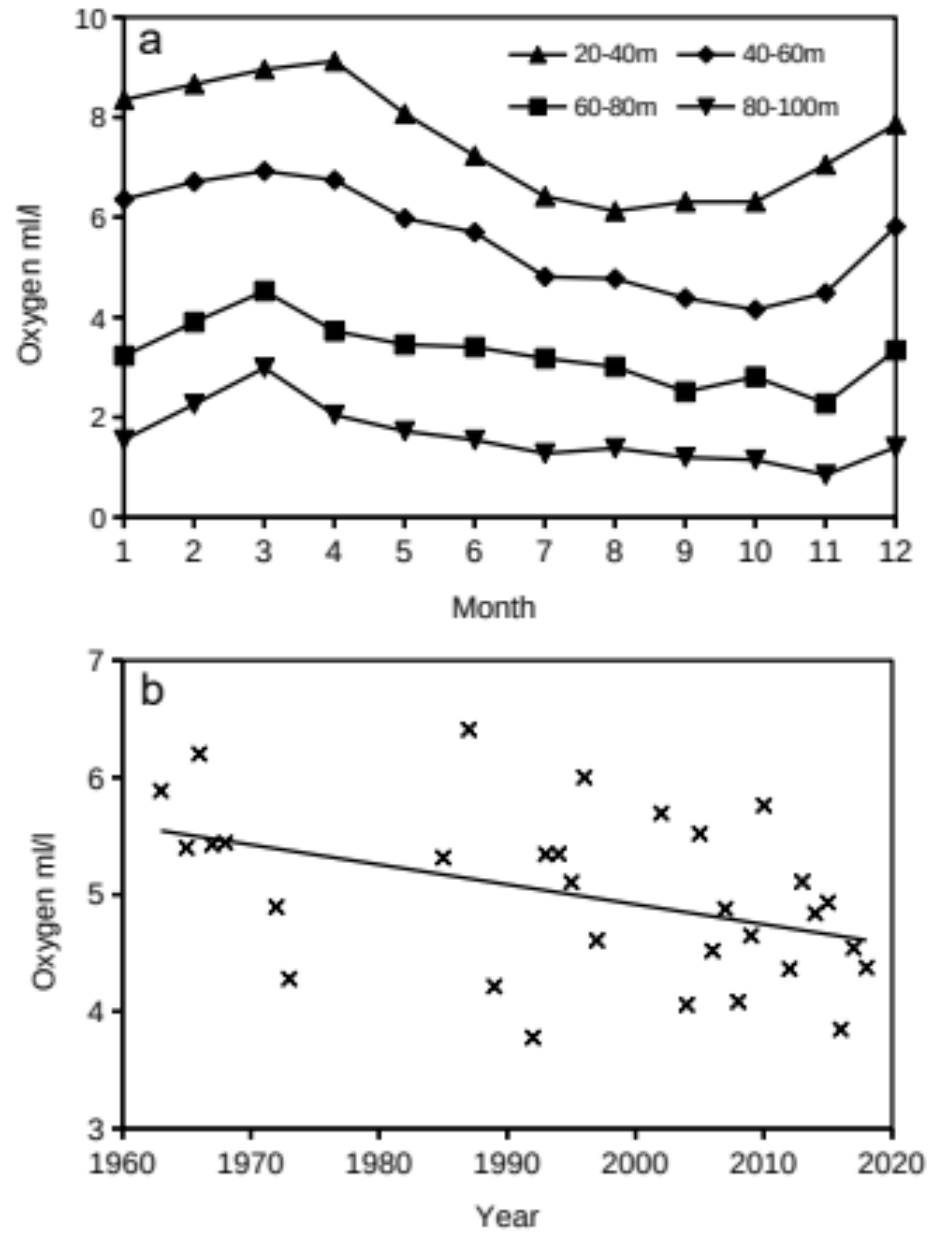

Figure 2 Variability in oxygen in the Baltic Sea SD25 (a) monthly by depth (b) annual 19632018 for 50-65m, the interquartile depth range of small cod. Months with fewer than five values and years with fewer than five months are excluded from the de-seasonalised annual values.

45 Evidence of the effect of low oxygen on feeding comes principally from an experiment with cod ( $\sim 45 \mathrm{~cm}$ in length and 700g weight) from the Gulf of St Lawrence (C\&D). The fish, kept at $\sim 10^{\circ} \mathrm{C}$ and a salinity of 28, were fed ad libitum on capelin. The consumption (g per fish per day) is shown in Figure 3. Percentage oxygen saturation levels on the x-axis of Figure $4 a$ of C\&D were converted using a $100 \%$ saturation value of $6.605 \mathrm{ml} / \mathrm{O} \mathrm{O}_{2}$ (the experiments were carried out at $10^{\circ} \mathrm{C}$ and salinity 28 ). A more

50 typical oxygen saturation value for the colder, fresher water of the Baltic Sea is $\sim 8 \mathrm{ml} / \mathrm{l}$ and the right hand y-axis of Figure 3 shows consumption level (\%) relative to the projected consumption at 8ml/1 (40g per fish per day projected from C\&D experiments). Thus, for example, consumption is projected to be $50 \%$ of the saturation level consumption when the oxygen level is $3.5 \mathrm{ml} / \mathrm{l}$ and falls to zero at $1.5 \mathrm{ml} / \mathrm{l}$. 
55 If the relationship from C\&D shown in Figure 3 applies to small cod in the Baltic Sea then we can infer that their ingestion rate is nearly always well below their maximum potential ingestion (roughly 40$80 \%$ of the maximum) due to low ambient oxygen. Oxygen-limited ingestion rate is subject to considerable seasonal and depth variability and small cod living at bottom depths of $<40 \mathrm{~m}$ during the first four months of the year may be close to their maximum potential ingestion rate.

60 Over the period 2004-2012 the average ambient oxygen level for $20-30 \mathrm{~cm}$ cod within their interquartile depth range was $4.73 \mathrm{ml} / \mathrm{l}$, giving a relative ingestion rate of $68 \%$. In years towards the end of the period, with lower ambient oxygen, the relative ingestion rate would be closer to 50\%. Deepening of the distribution of small cod by $2.5 \mathrm{~m}$ per decade (Orio et al. 2019) results in a further drop in ambient oxygen of roughly $0.25 \mathrm{ml} / \mathrm{l}$ per decade.

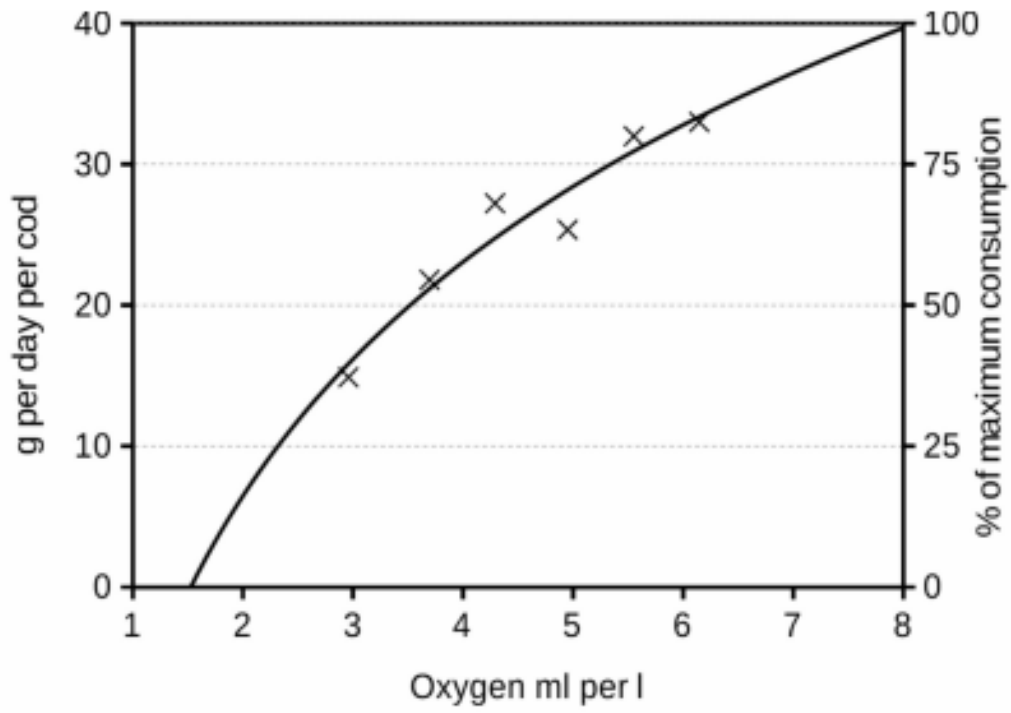
maximum consumption at $8 \mathrm{ml}$ oxygen per litre

It would be unwise to overlook the direct effect of ambient oxygen on feeding rates as a possible explanation of the observed changes in feeding and energy intake of small cod in the Baltic Sea, however additional work is required to provide a complete and reliable estimate of the impact of low oxygen. Previous studies have mentioned or included this mechanism (Casini et al. 2016; Limburg \& Casini, 2019; Pierce et al., 2017) but without quantifying it. Otolith microchemistry (Limburg and Casini 2019) has established that Baltic Sea cod (34-97cm) suffer from chronic hypoxia and that this is worse during summer months when oxygen levels are low. They adopt the standard definition of hypoxia as oxygen below $2 \mathrm{ml} / \mathrm{l}$, which occurs mainly at depths $>70 \mathrm{~m}$ and they discuss the vertical 
75 migrations of cod into such hypoxic zones. However small cod (20-30cm) mostly live at depths $<70 \mathrm{~m}$, are more dependent on benthos as food than bigger fish and seem unlikely to undertake vertical migrations like bigger fish. There have been no tagging studies of such small fish to show whether they migrate vertically.

The most obvious requirement for further study is to replicate experiments on the effect of oxygen on

80 ingestion rates of small $(20-30 \mathrm{~cm})$ Baltic Sea cod in order to test whether the existing relationship from C\&D is indeed valid for them too, as is assumed here.

It would be valuable to have better information on the behaviour of small cod; whether they remain close to the seabed or undertake regular vertical migrations. The observed deepening of their range by $2.5 \mathrm{~m}$ per decade would result in a worsening of their oxygen environment, which presumably is offset

85 by some other life history gain, such as evading predation in surface waters by seals and cormorants. For the cod population as a whole, their ambient oxygen may have changed over time due to deoxygenation of the Baltic Sea, but also to changes in their geographic and depth distribution. Since small cod occur mainly above 70m depth, greater efforts should probably be directed at investigating the effects of low ambient oxygen on them, rather than on what happens in depths greater than $70 \mathrm{~m}$ and 90 oxygen levels below $2 \mathrm{ml} / \mathrm{l}$.

Carstensen, J., Andersen, J. H., Gustafsson, B. G., \& Conley, D. J. (2014). Deoxygenation of the Baltic Sea during the last century. Proceedings of the National Academy of Sciences of the United States of America, 111(15), 5628-5633. https://doi.org/10.1073/pnas.1323156111

95 Casini, M., Käll, F., Hansson, M., Plikshs, M., Baranova, T., Karlsson, O., ... Hjelm, J. (2016). Hypoxic areas, density-dependence and food limitation drive the body condition of a heavily exploited marine fish predator. Royal Society Open Science, 3(10). https://doi.org/10.1098/rsos.160416

Chabot, D., \& Dutil, J. D. (1999). Reduced growth of Atlantic cod in non-lethal hypoxic conditions. Journal of Fish Biology, 55, 472-491.

Köster, F. W., Huwer, B., Hinrichsen, H. H., Neumann, V., Makarchouk, A., Eero, M., ... Plikshs, M. (2017). Eastern Baltic cod recruitment revisited - Dynamics and impacting factors. ICES Journal of Marine Science, 74(1), 3-19. https://doi.org/10.1093/icesjms/fsw172

Limburg, K. E., \& Casini, M. (2019). Otolith chemistry indicates recent worsened Baltic cod condition is linked to hypoxia exposure. Biology Letters, 15(12), 20190352. https://doi.org/10.1098/rsbl.2019.0352 
Neuenfeldt, S., Bartolino, V., Orio, A., Andersen, K. H., Andersen, N. G., Niiranen, S., ... Casini, M. (2019). Feeding and growth of Atlantic cod (Gadus morhua L.) in the East-ern Baltic Sea under environmental change. ICES Journal of Marine Science. https://doi.org/10.1093/icesjms/fsz224

110 Orio, A., Bergström, U., Florin, A. B., Lehmann, A., Šics, I., \& Casini, M. (2019). Spatial contraction of demersal fish populations in a large marine ecosystem. Journal of Biogeography, 46(3), 633645. https://doi.org/10.1111/jbi.13510

Pierce, M. E., Warnke, T., Krumme, U., Helms, T., Hammer, C., \& Uhrmacher, A. M. (2017).

Developing and validating a multi-level ecological model of eastern Baltic cod (Gadus morhua)

115 in the Bornholm Basin - A case for domain-specific languages. Ecological Modelling, 361, 4965. https://doi.org/10.1016/j.ecolmodel.2017.07.012 